\title{
Hot Rolling vs. Forging: Newly Developed Fe-Al-O Based OPH Alloy
}

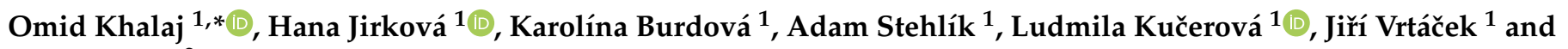 \\ Jiří Svoboda ${ }^{2}$
}

check for updates

Citation: Khalaj, O.; Jirková, H.; Burdová, K.; Stehlík, A.; Kučerová, L.; Vrtáček, J.; Svoboda, J. Hot Rolling vs. Forging: Newly Developed Fe-Al-O Based OPH Alloy. Metals 2021, 11, 228. https://doi.org/10.3390/met 11020228

Academic Editor: Irina P. Semenova Received: 7 December 2020

Accepted: 26 January 2021

Published: 28 January 2021

Publisher's Note: MDPI stays neutral with regard to jurisdictional claims in published maps and institutional affiliations.

Copyright: (c) 2021 by the authors. Licensee MDPI, Basel, Switzerland. This article is an open access article distributed under the terms and conditions of the Creative Commons Attribution (CC BY) license (https:// creativecommons.org/licenses/by/ $4.0 /)$.
1 Regional Technological Institute, University of West Bohemia, Univerzitní 8, 30100 Pilsen, Czech Republic; hstankov@rti.zcu.cz (H.J.); kburdova@rti.zcu.cz (K.B.); stehlika@rti.zcu.cz (A.S.); skal@rti.zcu.cz (L.K.); vrtacekj@rti.zcu.cz (J.V.)

2 Institute of Physics of Materials, Academy of Sciences of the Czech Republic, Žižkova 22, 61662 Brno, Czech Republic; svobj@ipm.cz

* Correspondence: khalaj@rti.zcu.cz; Tel.: +420-377-638783

\begin{abstract}
Two oxide precipitation hardened (OPH) Fe-Al-O-based steels were prepared by mechanical alloying. In addition to the variant using yttria nano-precipitates to improve the mechanical properties, a variant using only alumina precipitates for strengthening was also prepared. Therefore, a more economically acceptable variant of these steels was developed. Hot consolidation is a significant production step for achieving the required mechanical properties. Hot consolidation was performed by either hot rolling or forging. The heat treatment was subsequently performed on both variants $\left(0.85 \mathrm{Fe}-0.11 \mathrm{Al}-0.03 \mathrm{Y}_{2} \mathrm{O}_{3}-0.01 \mathrm{Y}\right.$ and $\left.0.87 \mathrm{Fe}-0.11 \mathrm{Al}-0.02 \mathrm{O}_{2}\right)$ of the alloys to support secondary recrystallization. The paper describes the influence of the consolidation method on grain size, material recrystallization, and mechanical properties. The difference in the consolidation method was reflected in the grain size after the heat treatment, where the material consolidated by hot rolling reached a grain size of almost $200 \mu \mathrm{m}$, while after forging the maximum grain size was around $30 \mu \mathrm{m}$. A higher ultimate tensile strength was achieved with forged states, both with and without the heat treatment.
\end{abstract}

Keywords: oxide precipitation hardened (OPH); forging; hot rolling; mechanical properties; microstructure; $\mathrm{Fe}-\mathrm{Al}-\mathrm{O}$

\section{Introduction}

Eco friendly energy and environmental industries are encountering some challenges related to the development and improvement of structural materials with regards to their different operating temperatures. One well-recognized candidate for this purpose is the nanostructured ferritic OPH alloy, which has significant high temperature mechanical properties [1-4], swelling and embrittlement compared to other similar materials such as austenitic steels $[5,6]$. Sakasegawa et al. found that the combination of oxide particles aggregate and coarsen during conventional casting processes as a result of the low solubility limit of the oxides in metals [7]. Mechanical alloying (MA) followed by hot consolidation processing is one of the most important steps for preparing OPH or ODS alloys. MA, in particular, is considered to have the greatest impact in the formation of a supersaturated solid solution and fine grains. It was originally developed for manufacturing Ni-based oxide dispersion strengthened (ODS) alloys for the aerospace industry [8]. Recently, ODS steels have been widely investigated for use in fabricating particle reinforced composites, which can lead to the uniform dispersion of nanosized oxides in the metal matrix [9-11]. Another important process is sintering which also has a significant influence on the mechanical properties and the microstructure of ODS alloys. Two common hot consolidated processes are hot rolling and forging [12-14]. In the consolidation process, some of the solid solution atoms such as $\mathrm{O}, \mathrm{Y}$, and Ti form nano-oxide precipitates by 
diffusion which then leads to grain coarsening. Hence, the evolution of the microstructure is highly controlled by the temperature and holding time. The orientation of the grains and the morphology are strongly dependent on the hot rolling direction, as well as forging. Forging is a multistep consolidation process where the samples can be rotated $90^{\circ}$ between successive passes. The processes can have significant effects on the crystallographic texture, plastic anisotropy and residual stress distribution, microstructure and the reduction of the directional dependency to create different properties in the forged material [15]. Other mechanical properties of ODS alloys are also strongly influenced by further thermomechanical treatments $[16,17]$. The annealing temperature and holding time can affect the oxide particles, grain growth, and recrystallization. However, heat treatments may result in a moderate improvement in the impact properties [18], while the mechanical anisotropy of these materials still remains a major concern $[19,20]$. It is confirmed that a greater blocking effect might lead to smaller nanoparticles, however, the influence of microstructure evolution on the mechanical properties of $\mathrm{OPH}$ alloys during rolling and forging need further study.

The OPH steel investigated in this study was produced by the mechanical alloying of $\mathrm{Fe}-\mathrm{Al}-\mathrm{O}$ powders. The main aim of this work is to trace and investigate the changes induced in the microstructure, as well as the mechanical properties after different annealing routes by comparing the effects of hot rolling and forging.

\section{Experimental Procedure}

\subsection{Material Preparation}

The new Fe-Al-based OPH steel is prepared from metal powders using a powder metallurgy [21]. Two systems were chosen for the experimental programme, OP1 containing $\mathrm{Y}$ and yttrium oxide, and OP2 containing Fe-Al-O (Table 1). The MA was done in a low energy ball mill developed by the authors in a vacuum. This method increases the density of defects in the matrix of the powder and the amount of oxygen dissolving in the matrix drastically increases by becoming trapped in the defects. Previous research shows that the solubility of interstitial oxygen in a heavily deformed matrix seems to be enormous [22]. It is necessary to be noted that after MA the powder is chemically homogeneous up to atomic size and includes an enormous number of defects such as dislocations and/or vacancies bearing a very high stored energy representing a significant driving force for microstructure evolution. Later, the powder is transferred to a low-alloy steel container with a diameter of $20 \mathrm{~mm}$ with no contact to the air, evacuated and sealed by welding. Two different processes were chosen for the consolidation.

Table 1. Material parameters for rolled and forged materials.

\begin{tabular}{|c|c|c|c|}
\hline $\begin{array}{l}\text { Material } \\
\text { No. }\end{array}$ & $\begin{array}{c}\text { Milling } \\
\text { Time (Days) }\end{array}$ & Annealing & $\begin{array}{l}\text { Chemical Composition } \\
\text { (wt.\%) }\end{array}$ \\
\hline OP1 & 20 & $\begin{array}{l}\text { without annealing } \\
1100{ }^{\circ} \mathrm{C}, 20 \mathrm{~h} ; 1200{ }^{\circ} \mathrm{C}, 20 \mathrm{~h} \\
\text { without annealing }\end{array}$ & $0.85 \mathrm{Fe}-0.11 \mathrm{Al}-0.03 \mathrm{Y}_{2} \mathrm{O}_{3}-0.01 \mathrm{Y}$ \\
\hline OP2 & 20 & $\begin{array}{l}1100^{\circ} \mathrm{C}, 20 \mathrm{~h} ; \\
1200^{\circ} \mathrm{C}, 20 \mathrm{~h}\end{array}$ & $0.87 \mathrm{Fe}-0.11 \mathrm{Al}-0.02 \mathrm{O}_{2}$ \\
\hline
\end{tabular}

A hot rolling mill is used to process the prepared materials with three hot rolling steps. First, the container is heated to a temperature of $900{ }^{\circ} \mathrm{C}$ for $20 \mathrm{~min}$ and rolled to a thickness of $7.5 \mathrm{~mm}$, which is then followed by the same passes for rolling to a thickness of 5 and $3.2 \mathrm{~mm}$. All the steps have a rolling speed of $0.2 \mathrm{~m} / \mathrm{s}$ and are made in the same rolling direction (Figure 1). An approximately $2.5 \mathrm{~mm}$ thick OPH sheet covered on both sides by a $0.3 \mathrm{~mm}$ thick scale from the rolling container is produced in this way. 


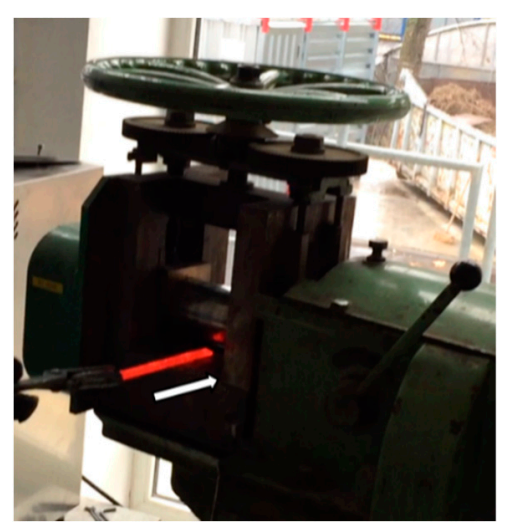

Figure 1. Rolling the heated container on the laboratory rolling mill.

Hot forging is used to produce bars from the OPH alloys. The containers were heated in an atmospheric furnace up to $1000{ }^{\circ} \mathrm{C}$ with a holding time of $40 \mathrm{~min}$. The forging was done on a hydraulic press in a shaped die. The initial semi-product was also a container with a diameter of $20 \mathrm{~mm}$. The container was held in tongs and manually rotated about its axis (Figure 2). After forging the length of the bar corresponding to the width of the anvils, the container was moved in the longitudinal direction, and the procedure was repeated. After reducing the diameter along the entire length of the bar in one die cavity, the bar was reheated to the forging temperature for $20 \mathrm{~min}$, and the procedure was repeated. The diameter was reduced in gradual steps to $16,14,12,11$, and $10 \mathrm{~mm}$. The bars were air cooled after forging. According to the diameter reduction, the true strain for rolling was 0.98 and for forging 0.7 .

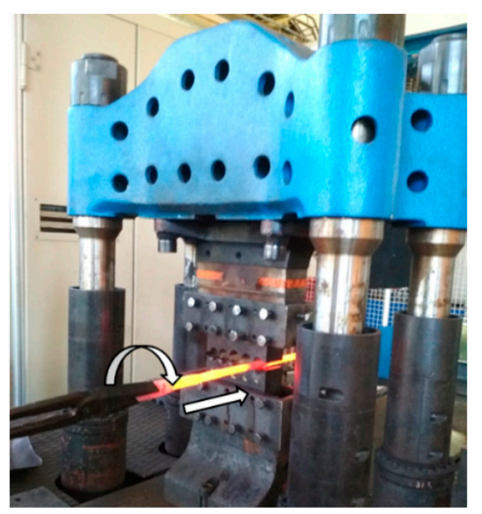

Figure 2. Forging the bar in the shaped die on the hydraulic press.

After both consolidation methods, the material is separated from the container and annealed at different temperatures and holding times (Table 1). In this study, two variants of OPH differing in chemical compositions are chosen, as shown in Table 1. OP1 consisted of the Fe-Al based OPH alloy with additional Yttrium and Yttrium oxide, while OP2 is composed of the Fe-Al OPH alloy. Yttrium was added to the OP1 alloy to increase the resistance of the nano-oxides to coarsening. This fact is clearly documented by the authors demonstrating that the replacement of $\mathrm{Al}$ oxides by $\mathrm{Y}$ oxides decreases their coarsening kinetics by about two orders of magnitude and thus, allows the applicability of the OPH alloy from 1000 to $1200{ }^{\circ} \mathrm{C}$ [21]. In OP2, only a very low cost alloy variant with aluminium was tried. The sufficient content of aluminium (typically over 5\%) ensures an excellent oxidation resistance by forming a compact alumina film on the surface, stabilizes the bcc-lattice, and enhances the static recrystallization leading to a coarse-grained structure with nano-oxides. Its increasing content, however, decreases the cohesive strength of the 
grain boundaries limiting the creep strength at very high temperatures and worsens the effectiveness of the mechanical alloying since the powder sticks to the walls of the milling container [23].

\subsection{Specimen Preparation}

In order to optimize the sample preparation process, standard mini tensile samples (gauge length $10 \mathrm{~mm}$, width $2 \mathrm{~mm}$, and average thickness $2.5 \mathrm{~mm}$ ) are prepared to fit in the tensile machine. A water jet cutting system is used to cut all the samples. The samples are cut in a longitudinal direction (parallel to the rolling/forging direction), and the thickness of the specimens is approximately $2.5 \mathrm{~mm}$ after grinding.

\subsection{Testing Equipment and Procedure}

A servo-hydraulic MTS thermomechanical simulator (MTS, Minnesota, MN, USA) and a UHL/VMHT hardness tester (Walter Uhl, Asslar, Germany) were used for the mechanical tests. Purpose-built convertors (UWB, Pilsen, Czech Republic) were manufactured by the authors to hold the samples on the servo-hydraulic MTS. All tensile tests were carried out with a strain rate of $1 \times 10^{3} \mathrm{~s}^{-1}$. Three samples were tested for each state and the average values of ultimate tensile strength (UTS), and elongation to failure (A) were statistically calculated. The hardness tests were performed with a load of $10 \mathrm{~kg}$ and loading time of $11 \mathrm{~s}$ on the head of the surface of the polished samples. The average value was calculated from three measurements. Samples for a metallographic evaluation were taken in the longitudinal direction, i.e., in the direction of rolling and elongation during forging. Samples were prepared using standard grinding and polishing processes. The overview images of the obtained microstructure were observed using light microscopy. A scanning electron microscope (SEM), Tescan LYRA 3 (Tescan, Brno, Czech Republic), was used for a detailed metallographic analysis of the samples. For observation on a light microscope, the structure was etched with 3\% Nital. For SEM, the last polishing step was performed with an oxide polishing suspension (OPS). For the grain size measurement, the interception method according to ASTM E112 was used. In the case of elongation of grains due to deformation, the measurement was performed in the longitudinal and transverse direction and the grain size was determined as the average value from these measurements.

\section{Results and Discussion}

\subsection{Metallographic Analysis}

The microstructure after powder consolidation by rolling or forging consisted of very fine, nearly equiaxed ferrite grains with nano precipitates (Figure 3a-d). Depending on the chemical composition, the nano precipitates in the OP2 material are based on aluminium and in the OP1 material the precipitates are rich in yttrium. Elongation of grains in the direction of rolling or forging was not observed. The grain size measurement showed that after consolidation by rolling, the grain size was between 0.16 to $0.169 \mu \mathrm{m}$ for both experimental alloys (Table 2). The hardness for material OP1 with yttrium reached 554 HV10. A higher hardness of 618 HV10 was observed for the material OP2 stabilised by aluminium. The forging led to a coarsening of the grain size up to $0.185 \mu \mathrm{m}$ in the case of the OP1 alloy and up to 0.216 for the OP2 alloy (Table 2). Moreover, the size of precipitates increased, especially for the OP2 material (Figure 3d). The growth of precipitates during forging consolidation may be due to the repeated heating to a forging temperature of $1000{ }^{\circ} \mathrm{C}$. The value of hardness was $483 \mathrm{HV} 10$ for OP1, and 495 HV10 for OP2 (Table 2). 


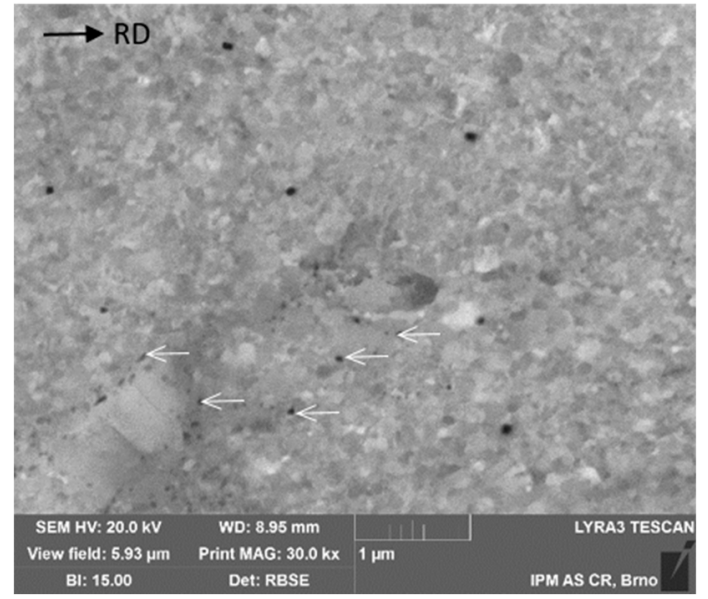

(a)

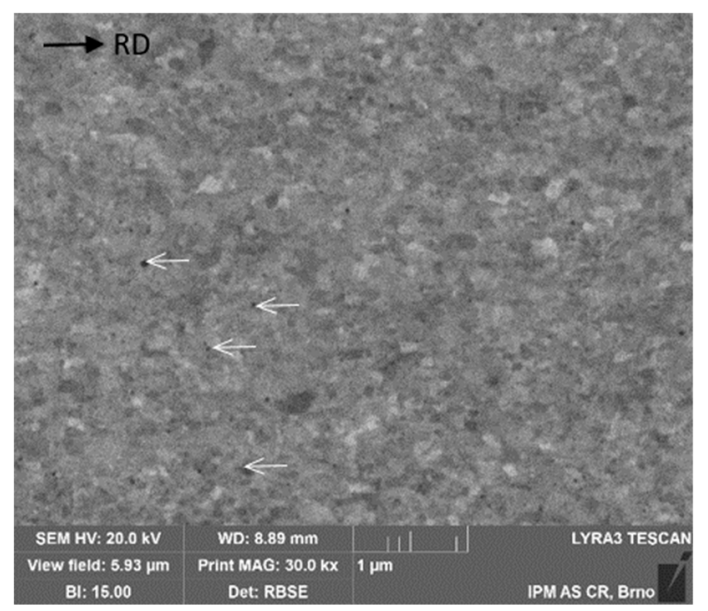

(c)

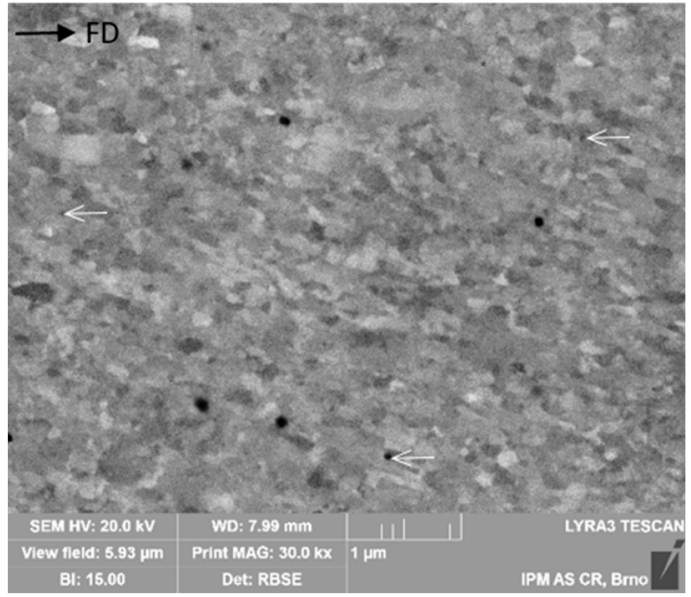

(b)

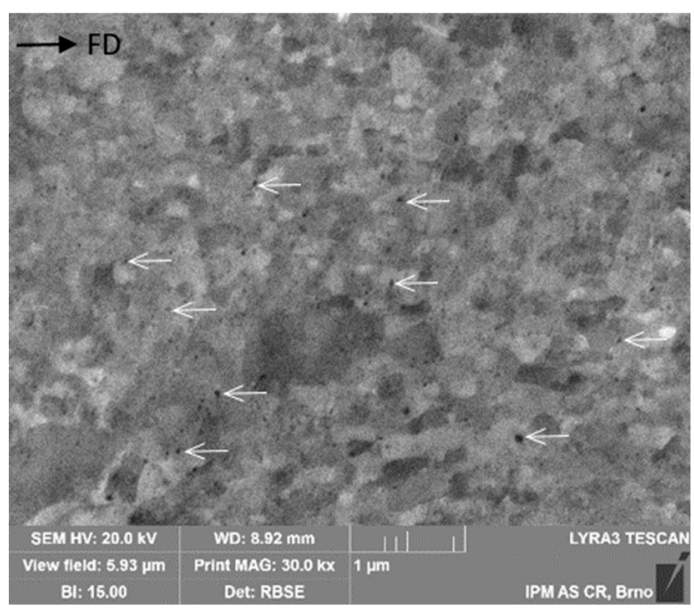

(d)

Figure 3. Microstructures from scanning electron microscope imaging of the consolidated alloys: (a) oxide precipitation (OP1) — after rolling, (b) OP1—after forging, (c) OP2—after rolling, (d) OP2 —after forging (RD—rolling direction, FD— forging direction, arrows-precipitates).

Table 2. Grain size and hardness of the experimental alloys after different heat treatments.

\begin{tabular}{|c|c|c|c|c|c|c|}
\hline \multirow[b]{2}{*}{ Material } & \multicolumn{3}{|c|}{ Grain Size $(\mu \mathrm{m})$} & \multicolumn{3}{|c|}{ HV10 (-) } \\
\hline & Initial State & $\begin{array}{c}1100{ }^{\circ} \mathrm{C} \\
20 \mathrm{~h}\end{array}$ & $\begin{array}{c}1200{ }^{\circ} \mathrm{C} \\
20 \mathrm{~h}\end{array}$ & Initial State & $\begin{array}{c}1100{ }^{\circ} \mathrm{C} \\
20 \mathrm{~h}\end{array}$ & $\begin{array}{c}1200{ }^{\circ} \mathrm{C} \\
20 \mathrm{~h}\end{array}$ \\
\hline OP1 rolled & 0.16 & 147.6 & 197.7 & 554 & 365 & 320 \\
\hline OP1 forged & 0.185 & 16.8 & 18.1 & 483 & 423 & 343 \\
\hline OP2 rolled & 0.169 & 51.1 & 86.3 & 618 & 403 & 346 \\
\hline OP2 forged & 0.216 & 13.8 & 26.9 & 495 & 341 & 299 \\
\hline
\end{tabular}

Due to annealing, the grains gradually coarsened, and the hardness value decreased (Figures 4-7). The yttrium (OP1) alloyed material showed a 34\% hardness decrease with annealing at $1100{ }^{\circ} \mathrm{C}$ for $20 \mathrm{~h}$, and after annealing at $1200{ }^{\circ} \mathrm{C} / 20 \mathrm{~h}$, the decrease was $42 \%$ from the initial state (Table 2). The same behaviour was found in the system with Al (OP2). Hardness also decreased by $34 \%$ in the case of annealing at $1100{ }^{\circ} \mathrm{C}$. The higher annealing temperature of $1200{ }^{\circ} \mathrm{C}$ caused a further hardness reduction by $44 \%$ in comparison to the initial state. The effect of heat treatment is visible on the grain growth. Due to the ongoing recrystallization, there was a significant increase in grain size, which increased 
from hundreds of nanometres to tens of micrometres (Figures 4 and 6, Table 2). In the case of the yttrium-alloyed material (OP1), the grain size increased up to $197.7 \mu \mathrm{m}$.

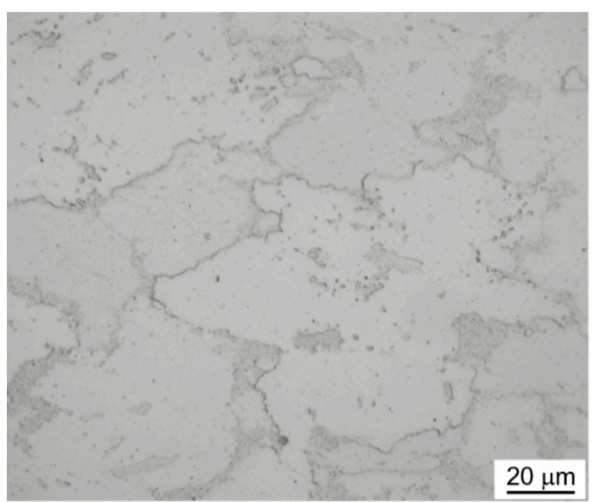

(a)

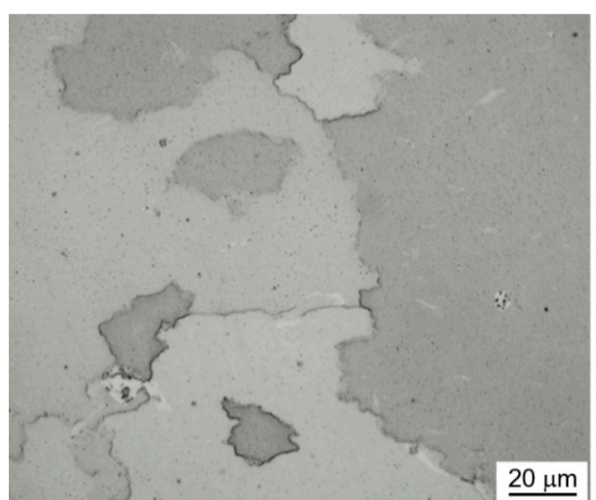

(b)

Figure 4. Effect of heat treatment on the microstructure (light microscope) of rolled OP1 (a) $1100{ }^{\circ} \mathrm{C} / 20 \mathrm{~h}$ and (b) $1200{ }^{\circ} \mathrm{C} / 20 \mathrm{~h}$.

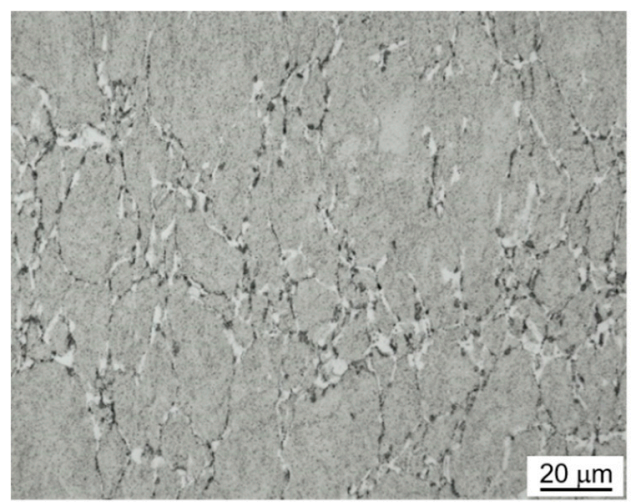

(a)

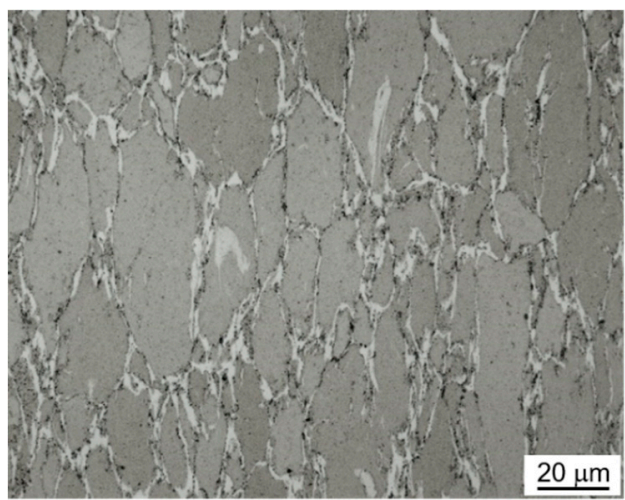

(b)

Figure 5. Effect of heat treatment on the microstructure (light microscope) of forged OP1 (a) $1100{ }^{\circ} \mathrm{C} / 20 \mathrm{~h}$ and (b) $1200{ }^{\circ} \mathrm{C} / 20 \mathrm{~h}$.

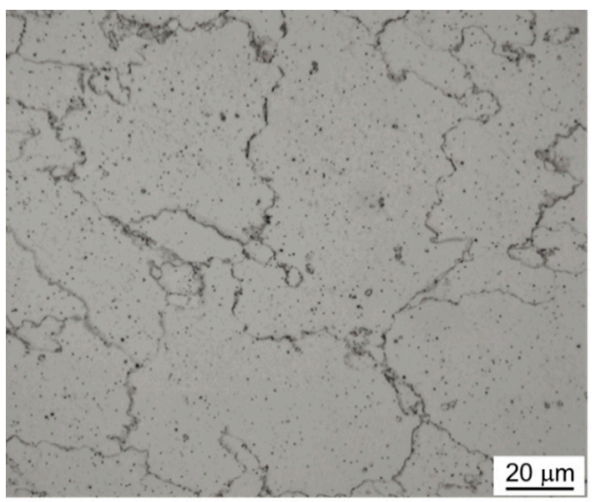

(a)

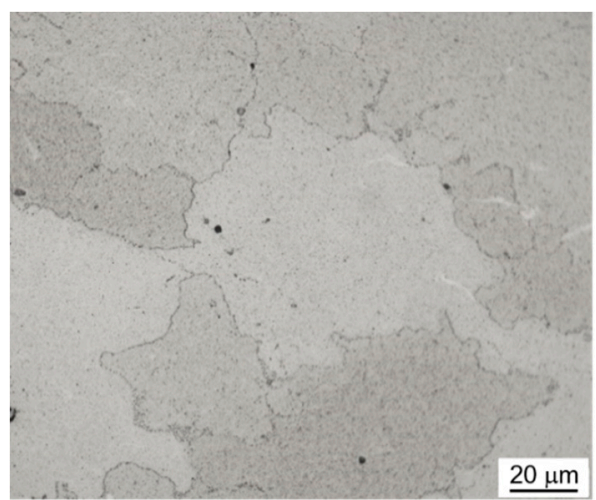

(b)

Figure 6. Effect of heat treatment on the microstructure (light microscope) of rolled OP2 (a) $1100{ }^{\circ} \mathrm{C} / 20 \mathrm{~h}$ and (b) $1200{ }^{\circ} \mathrm{C} / 20 \mathrm{~h}$. 


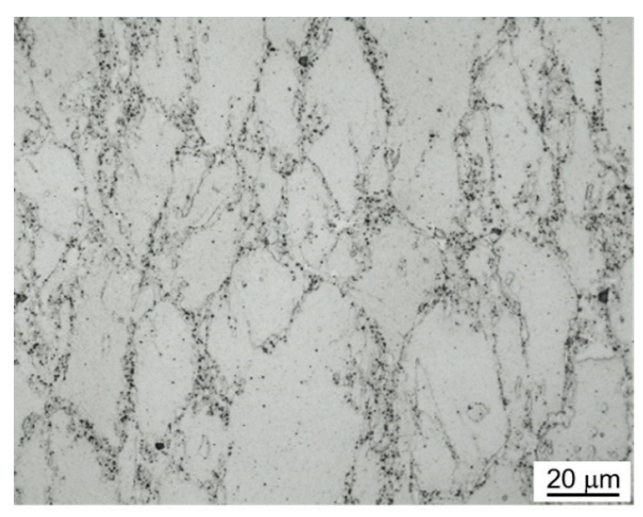

(a)

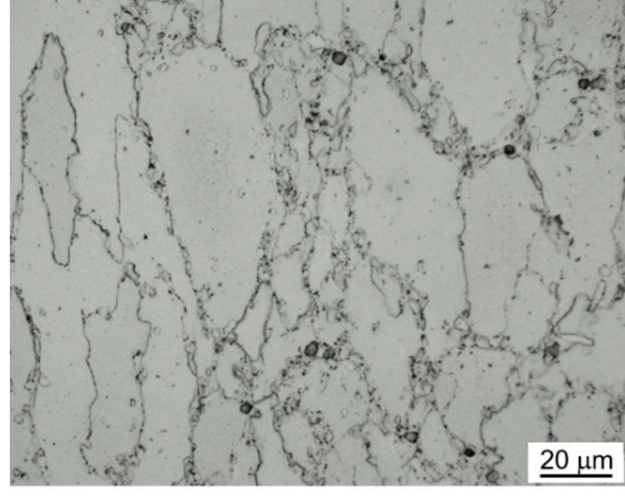

(b)

Figure 7. Effect of heat treatment on the microstructure (light microscope) of forged OP2 (a) $1100{ }^{\circ} \mathrm{C} / 20 \mathrm{~h}$ and (b) $1200{ }^{\circ} \mathrm{C} / 20 \mathrm{~h}$.

The samples obtained by forging did not show such a significant decrease in hardness values after the heat treatment. In the case of the material with yttrium (OP1), the hardness decreased by only $12 \%$, and $30 \%$ after the application of individual heat treatment regimes. A more significant decrease was found in the material with $\mathrm{Al}(\mathrm{OP} 2)$, where there was a decrease in hardness by $31 \%$ for annealing at $1100{ }^{\circ} \mathrm{C}$, and $40 \%$ for $1200{ }^{\circ} \mathrm{C}$. The heat treatment did not lead to a significant coarsening of the grain in the case of forging. The grain size after the heat treatment was around 16 to $30 \mu \mathrm{m}$ (Figures 5 and 7 ).

The lower reduction in hardness as well as the smaller grain size after consolidation by forging the material can be explained by the smaller degree of strain in individual reductions during forging. Forging took place in five passes, while the final thickness by rolling was reached after only three reductions.

\subsection{Mechanical Properties}

Figure 8 gives the engineering stress-strain extracted from the mini-tensile tests for both OPH alloy samples subjected to heat treatments at temperatures ranging from 1100 to $1200^{\circ} \mathrm{C}$. The ultimate tensile strength (UTS) values are defined as the stresses corresponding to the highest point of the stress-strain curve. The UTS and yield strength reveal similar features, so only UTS is used as a comparative parameter.

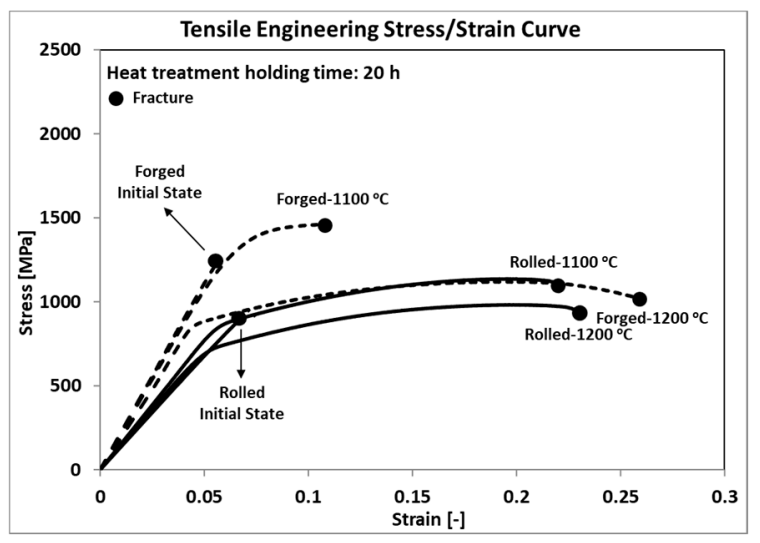

(a)

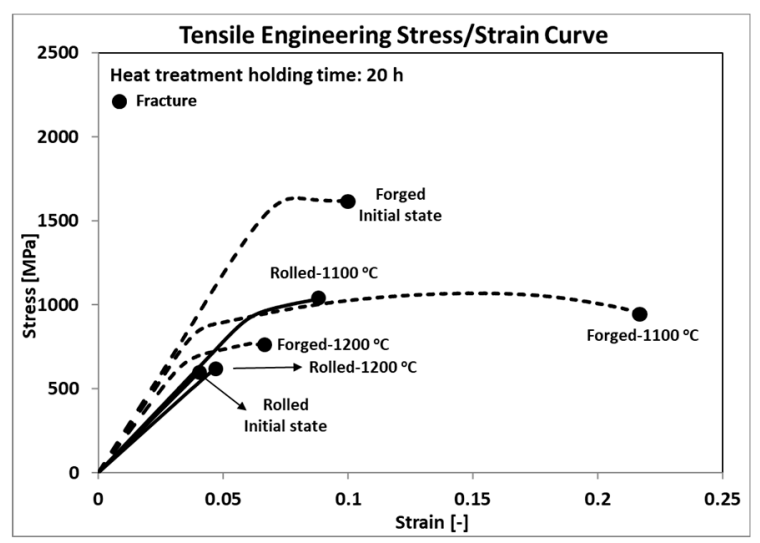

(b)

Figure 8. Tensile engineering stress-strain curves for (a) OP1 and (b) OP2.

It can be observed that both yield and ultimate tensile strength values achieve their highest values when the samples were forged, without annealing. As can be seen from the experiments, the difference between the samples heat treated up to $1200{ }^{\circ} \mathrm{C}$ is not very 
pronounced, in agreement with the hardness measurements. Previous experiences of the authors show that the average UTS for such an OPH with similar chemical components is between 800 to $1000 \mathrm{MPa}$ [24-29], which confirms the measured results. In both cases, a reduction in UTS which is then followed by an increase in elongation, was observed. In addition, forged samples generally look improved, especially without the heat treatment (initial state), when compared to the rolled ones. Figure 8a shows that by holding the OP1 forged variant at $1100{ }^{\circ} \mathrm{C}$ for $20 \mathrm{~h}$ we can increase the UTS to approximately $1500 \mathrm{MPa}$, while the rolled variants under the same conditions show almost $1000 \mathrm{MPa}$. Considering the initial states, the forged samples showed great improvements in UTS compared to the rolled samples, while it increased by $50 \%$ for both OP1 and OP2.

The ultimate tensile strengths (UTS) of the forged materials are considerably higher, within the full range of annealing temperatures, but the total elongation is much lower than that for the rolled OPH alloys. The effect of work hardening after annealing is obvious for both forged and rolled variants. However, the influence of the rolling process on the ductility of the OPH steel, especially at elevated temperatures cannot be neglected. On the other hand, such a high value of UTS may be caused by the high density of oxides in the $\mathrm{OPH}$ alloy. The influence of excess oxygen on the tensile strength is also confirmed by a previous research $[24,26,27,29,30]$, which stated that the highest UTS is almost achieved for a low content of $0.12 \%$ oxygen, while a higher excess oxygen made the tensile properties in a different way.

To get a better overview of the impact of forging on the UTS, Figure 9 compares the UTS values with the heat treatment (HT) temperatures for both forged and rolled samples. All the annealed samples as well as the initial state (IS) confirmed the improvement of the UTS using forging as the consolidation method. However, it varied as the HT temperature changed.

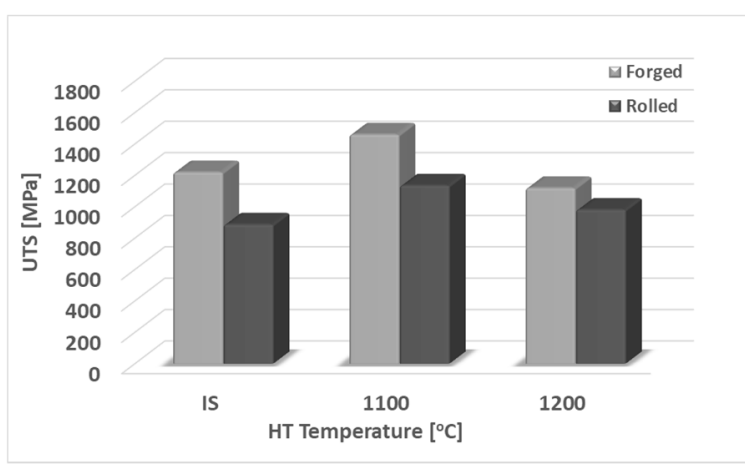

(a)

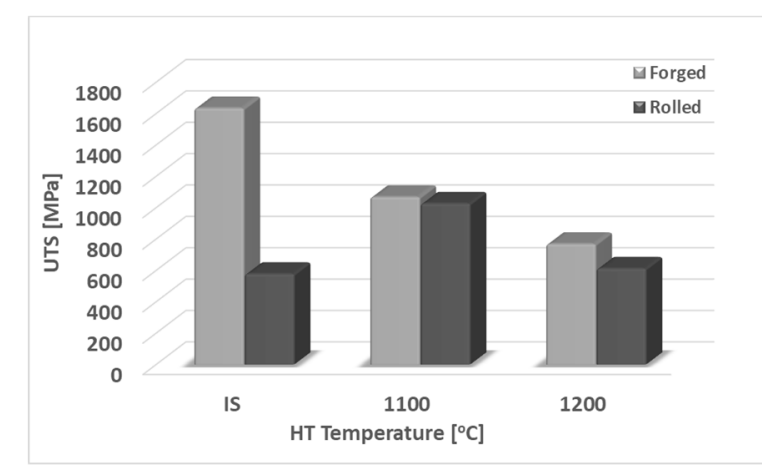

(b)

Figure 9. Ultimate tensile strengths (UTS) against the heat treatment (HT) for (a) OP1 and (b) OP2.

With an increase in the HT temperature, both OP1 and OP2 show reductions in the improvement of UTS using the forging method. However, the rolled samples show a peak in UTS after annealing at $1100{ }^{\circ} \mathrm{C}$. The same was observed for the OP1 forged sample, which can explain the decrease in the value of elongation. This may be due to the fact that the excess oxygen is not bound in stable oxides. In most cases, the solubility of oxygen in the matrix is practically zero, and all the oxygen is present in the oxides of elements with the highest affinity to oxygen. That is the main reason for the UTS variation due to strengthening by oxides. On the other hand, the fluctuation of tensile properties correlates with the different grain and oxide particle distribution, while the hard dispersoids such as oxides are bypassed by the formation of Orowan loops. In addition, the uniform distribution of grains and oxide particles, based on the consolidation method, also affect the ductility of ODS steels. Moreover, a high excess oxygen concentration may cause an inhomogeneous microstructure with a co-existence of fine and coarse oxide particles as well as grains, which 
could lead to a decrease of UTS. The increase in UTS is a result of cumulative strengthening increments of the grain boundary, so called Hall-Petch strengthening, as well as dispersion strengthening (Orowan strengthening), as explained above. The observed higher strength is due to the presence of fine grains and dispersoids [31].

\section{Conclusions}

The mechanical properties, hardness, and microstructures of two different variants of a newly developed Fe-Al-O-based OPH alloy prepared by two different consolidation methods were investigated using various tests.

After hot consolidation, the grain size was between 160-216 nm. After hot rolling, the grain size was smaller for both investigated alloys. The difference between the rolled and forged materials was between 25 and $47 \mathrm{~nm}$. The consolidation method had a significant influence on the recrystallization of the material and the grain growth. In the case of the rolled states, there was a thousand-times increase in the grain size compared to the forged state, where the increase was only a hundred times. This difference in grain size was reflected in the mechanical properties. Due to the grain size, higher UTS values were obtained for the forged materials both in the initial state and after the heat treatment.

Author Contributions: Conceptualization, J.S., H.J., and O.K.; methodology, O.K., H.J., and J.S.; software, O.K. and H.J.; validation, O.K., H.J., J.S., A.S., and K.B.; formal analysis, O.K., L.K. and H.J.; investigation, O.K., H.J., A.S., and J.V.; resources, O.K., J.S., and H.J.; data curation, O.K., J.S., H.J., and A.S.; writing - original draft preparation, O.K. and H.J.; writing-review and editing, O.K., J.S., L.K. and H.J.; visualization, O.K. and H.J.; supervision, J.S.; project administration, H.J.; funding acquisition, J.S. and H.J. All authors have read and agreed to the published version of the manuscript.

Funding: This paper includes results created within the project 17-01641S Improvement of Properties and Complex Characterization of New Generation Fe-Al-O-based Oxide Precipitation Hardened Steels, subsidised by the Czech Science Foundation from specific resources of the state budget of the Czech Republic for research and development. "The APC was funded by 1500 CHF".

Institutional Review Board Statement: Not applicable.

Informed Consent Statement: Not applicable.

Data Availability Statement: The raw/processed data required to reproduce these findings cannot be shared at this time as the data also forms part of an ongoing study.

Acknowledgments: K.B. and L.K. thank the student grant competition of the University of West Bohemia in Pilsen, SGS 2019-019.

Conflicts of Interest: The authors declare no conflict of interest.

\section{References}

1. Ohtsuka, S.; Ukai, S.; Fujiwara, M. Nano-mesoscopic structural control in 9CrODS ferritic/martensitic steels. J. Nucl. Mater. 2006, 351, 241-246. [CrossRef]

2. Sugino, Y.; Ukai, S.; Leng, B.; Oono, N.; Hayashi, S.; Kaito, T.; Ohtsuka, S. Grain boundary related deformation in ODS ferritic steel during creep test. Mater. Trans. 2012, 53, 1753-1757. [CrossRef]

3. Kaito, T.; Ohtsuka, S.; Inoue, M.; Asayama, T.; Uwaba, T.; Mizuta, S.; Ukai, S.; Furukawa, T.; Ito, C.; Kagota, E.; et al. In-pile creep rupture properties of ODS ferritic steel claddings. J. Nucl. Mater. 2009, 294-298. [CrossRef]

4. Klueh, R.L.; Shingledecker, J.P.; Swindeman, R.W.; Hoelzer, D.T. Oxide dispersion-strengthened steels: A comparison of some commercial and experimental alloys. J. Nucl. Mater. 2005, 341, 103-114. [CrossRef]

5. Wang, M.; Liu, Q.; Sun, Y.J.; Che, Y.S.; Jiang, C.Z. Photocatalytic property of Eu/BiVO4 photocatalyst by citric acid Sol-Gel method. Wuji Cailiao Xuebao J. Inorg. Mater. 2013, 28, 153-158. [CrossRef]

6. Oka, H.; Watanabe, M.; Kinoshita, H.; Shibayama, T.; Hashimoto, N.; Ohnuki, S.; Yamashita, S.; Ohtsuka, S. In situ observation of damage structure in ODS austenitic steel during electron irradiation. J. Nucl. Mater. 2011, 417, 279-282. [CrossRef]

7. Sakasegawa, H.; Tamura, M.; Ohtsuka, S.; Ukai, S.; Tanigawa, H.; Kohyama, A.; Fujiwara, M. Precipitation behavior of oxide particles in mechanically alloyed powder of oxide-dispersion-strengthened steel. J. Alloy. Compd. 2008, 452, 2-6. [CrossRef]

8. Intrater, J. Mechanical Alloying and Milling; Suryanarayana, C., Ed.; Taylor \& Francis: Abingdon, UK, 2007.

9. Brocq, M.; Radiguet, B.; Le Breton, J.M.; Cuvilly, F.; Pareige, P.; Legendre, F. Nanoscale characterisation and clustering mechanism in an Fe-Y2O3 model ODS alloy processed by reactive ball milling and annealing. Acta Mater. 2010, 58, 1806-1814. [CrossRef] 
10. Parida, P.K.; Dasgupta, A.; Jayasankar, K.; Kamruddin, M.; Saroja, S. Structural studies of Y2O3 dispersoids during mechanical milling and annealing in a Fe-15 Y2O3 model ODS alloy. J. Nucl. Mater. 2013, 441, 331-336. [CrossRef]

11. Khalaj, O.; Ghobadi, M.; Zarezadeh, A.; Saebnoori, E.; Jirková, H.; Chocholaty, O.; Svoboda, J. Potential role of machine learning techniques for modeling the hardness of OPH steels. Mater. Today Commun. 2020, 101806. [CrossRef]

12. Tokunaga, T.; Ohno, M. Compounds. Microstructure evolution during superplastic deformation of an Al-coated Mg alloy sheet. J. Alloy. Compd. 2019, 805, 436-443. [CrossRef]

13. Leo, J.; Barroso, S.P.; Fitzpatrick, M.; Wang, M.; Zhou, Z.J.M.S.; A, E. Microstructure, tensile and creep properties of an austenitic ODS 316L steel. Mater. Sci. Eng. A 2019, 749, 158-165. [CrossRef]

14. Li, Z.; Chen, L.; Zhang, H.; Zhang, S.; Zhang, Z. Effect of annealing temperature on microstructure and mechanical properties in oxide dispersion strengthened Fe-14Cr alloys prepared by spark plasma sintering. Mater. Res. Express 2019, 6, 126515. [CrossRef]

15. Rout, M.; Pal, S.K.; Singh, S.B. Cross rolling: A metal forming process. In Modern Manufacturing Engineering; Springer: Berlin/Heidelberg, Germany, 2015; pp. 41-64.

16. He, P.; Lindau, R.; Moeslang, A.; Sandim, H.R.Z. Design. The influence of thermomechanical processing on the microstructure and mechanical properties of 13.5 Cr ODS steels. Fusion Eng. Des. 2013, 88, 2448-2452. [CrossRef]

17. Krishna, S.C.; Karthick, N.; Jha, A.K.; Pant, B.; Cherian, R.M. Performance. Effect of Hot Rolling on the Microstructure and Mechanical Properties of Nitrogen Alloyed Austenitic Stainless Steel. J. Mater. Eng. Perform. 2018, 27, 2388-2393. [CrossRef]

18. Oksiuta, Z.; Lewandowska, M.; Kurzydlowski, K.; Baluc, N.J. Influence of hot rolling and high speed hydrostatic extrusion on the microstructure and mechanical properties of an ODS RAF steel. J. Nucl. Mater. 2011, 409, 86-93. [CrossRef]

19. Stork, D.; Agostini, P.; Boutard, J.-L.; Buckthorpe, D.; Diegele, E.; Dudarev, S.; English, C.; Federici, G.; Gilbert, M.; Gonzalez, S.; et al. Developing structural, high-heat flux and plasma facing materials for a near-term DEMO fusion power plant: The EU assessment. J. Nucl. Mater. 2014, 455, 277-291. [CrossRef]

20. Fournier, B.; Steckmeyer, A.; Rouffie, A.-L.; Malaplate, J.; Garnier, J.; Ratti, M.; Wident, P.; Ziolek, L.; Tournie, I.; Rabeau, V.; et al. Mechanical behaviour of ferritic ODS steels-Temperature dependancy and anisotropy. J. Nucl. Mater. 2012, 430, 142-149. [CrossRef]

21. Khalaj, O.; Saebnoori, E.; Jirková, H.; Chocholatý, O.; Svoboda, J. High Temperature and Corrosion Properties of A Newly Developed Fe-Al-O Based OPH Alloy. Metals 2020, 10, 167. [CrossRef]

22. Bártková, D.; Šmíd, M.; Mašek, B.; Svoboda, J.; Šiška, F. Kinetic study of static recrystallization in an Fe-Al-O ultra-fine-grained nanocomposite. Philos. Mag. Lett. 2017, 97, 379-385. [CrossRef]

23. Dymáček, P.; Svoboda, J.; Jirková, H.; Stratil, L.; Horník, V. Microstructure evolution and creep strength of new-generation oxide dispersion strengthened alloys with high volume fraction of nano-oxides. Procedia Struct. Integr. 2019, 17, 427-433. [CrossRef]

24. Khalaj, O.; Jirková, H.; Janda, T.; Kucerova, L.; Svoboda, J. Improving the High Temperature Properties of a New Generation of Fe-Al-O Oxide Precipitation Hardened Steels. Mater. Technol. 2019, 53, 495-504.

25. Khalaj, O.; Jirková, H.; Jeníček, Š.; Račický, A.; Svoboda, J. Annealing effects on the microstructure and thermomechanical properties of New-Generation ODS Alloys. In Key Engineering Materials; Trans Tech Publications Ltd.: Bäch, Switzerland, 2020; Volume 834, pp. 67-74. [CrossRef]

26. Khalaj, O.; Jirkova, H.; Masek, B.; Hassasroudsari, P.; Studecky, T.; Svoboda, J. Using Thermomechanical Treatments to Improve the Grain Growth of New-Generation Ods Alloys. Mater. Tehnol. 2018, 52, 475-482. [CrossRef]

27. Khalaj, O.; Masek, B.; Jirkova, H.; Ronesova, A.; Svoboda, J. Investigation on New Creep- and Oxidation-Resistant Materials. Mater. Tehnol. 2015, 49, 645-651. [CrossRef]

28. Khalaj, O.; Saebnoori, E.; Jirková, H.; Chocholaty, O.; Svoboda, J. Corrosion Behavior and Mechanical Properties of New Developed Oxide Precipitation Hardened Steels. In Key Engineering Materials; Trans Tech Publications Ltd.: Bäch, Switzerland, 2020; Volume 846, pp. 87-92. [CrossRef]

29. Svoboda, J.; Hornik, V.; Stratil, L.; Hadraba, H.; Masek, B.; Khalaj, O.; Jirkova, H. Microstructure Evolution in ODS Alloys with a High-Volume Fraction of Nano Oxides. Metals 2018, 8, 1079. [CrossRef]

30. Svoboda, J.L.N.; Jarý, M.; Dymáček, P. Influence of Hot Consolidation Conditions and Cr-Alloying on Microstructure and Creep in New-Generation ODS Alloy at $1100{ }^{\circ} \mathrm{C}$. Materials 2020, 13, 5070. [CrossRef]

31. Nagini, M.; Vijay, R.; Rajulapati, K.V.; Reddy, A.; Sundararajan, G. Microstructure-mechanical property correlation in oxide dispersion strengthened 18Cr ferritic steel. Mater. Sci. Eng. A 2017, 708, 451-459. [CrossRef] 